\title{
Trade and Women Employment in China: An Insight into the Low Presence of Women Workforce in the 21st Century Corporate China
}

\author{
Anirban Nandi \\ Tim \& Steph Busch School of Business \& Economics, The Catholic University of America, Washington DC, USA \\ Email: nandi@cua.edu
}

How to cite this paper: Nandi, A. (2019) Trade and Women Employment in China: An Insight into the Low Presence of Women Workforce in the 21st Century Corporate China. Open Journal of Business and Management, 7, 70-92.

https://doi.org/10.4236/ojbm.2019.71005

Received: October 23, 2018

Accepted: December 2, 2018

Published: December 5, 2018

Copyright $\odot 2019$ by author and Scientific Research Publishing Inc. This work is licensed under the Creative Commons Attribution International License (CC BY 4.0).

http://creativecommons.org/licenses/by/4.0/

\begin{abstract}
As China enjoys being the second largest economy in the world, it's women can said to have the credit for its country's economic development in this 21 st century. This paper studies the women employment factor in China and identifies the issue of lower female workforce in Chinese businesses despite of Chinese women, from various walks of life excelling in the corporate world, and studies their income and the employment discrimination faced by them. This research takes a correlation methodology approach to establish the cause of such lower women presence in the Chinese businesses. The study uses regression analysis to establish the relationships between the women employed in Chinese businesses and the success rate of those businesses. The rate of discrimination against women in employment by viz. family, male peers and company officials is also being determined. The research concludes with women's significance in big Chinese corporate giants highlighting their contribution towards them through continued presence, the need of increasing female income and bringing in a level playing field for women through equal opportunity policies, the future prediction on the rate of firm profits and the need for further research on the broader aspects of the issue specific to the topic in concern.
\end{abstract}

\section{Keywords}

Trade, Women Employment, Women Workforce, Employment in China, Chinese Trade

\section{Introduction}

This research intends to look into the women's employment in various businesses across China and through this, focusing mainly on establishing the cause 
for lower presence of women workforce in the Chinese businesses. This paper primarily has two significant motives, first to study the reluctance of Chinese employers in China to hire and promote female workforce to well-paid jobs, and second to study the aspect of "dislike" against women by their male peers and company officials. This research aims to institute the primary cause for such a low female workforce presence in Chinese businesses through answering these two primary issues.

Previous studies on trade and women employment in Chinese businesses have been seen taking primary, secondary and also multiple linear regression approach to the topic where authors have used survey reports from the government, collected data from Chinese businesses and also based their study on the data reviewed from research conducted by other authors. Further, they have also used multiple linear regression to distinguish and analyze different variables to come to a conclusion. Therefore, this paper will also take correlation method throughout the study using multiple linear regression in order to highlight the primary issues pertaining to the topic, and make comparisons with previous researches wherever necessary. The results and findings of this research are based on the outcomes of the regression analysis and correlation coefficients, which helps to identify the relationship between the women employed in Chinese businesses, their income, employment discrimination against them and the success rate of those businesses, and also establishes the rate of discrimination against women in employment through pie chart depiction. These perhaps also form as the rationale for this study.

Women have always been a crucial aspect of Chinese businesses. Erdenebileg (2016) [1] states in her research that during the 1970's, employment of women was holding up the sky for Chinese businesses, which was also said to have been remarked by Chairman Mao of China, it evidently indicates the significance of Chinese women in the welfare of the businesses across China. Female employment in China across various businesses have seen a sharp rise in the past few years and today, it plays a pivotal role in the success of any business within the country. One of the modern distinctive features of Chinese society is to bring in more and more women out of the traditional family household and make them to participate in trade and businesses, so that they can display their skills and contributions to the Chinese economy, as indicated in a research by Xiaoping (2000) [2]. This statement is indicative of the fact that the core foundation of modern China is based on the concept that women participation in businesses across China is highly regarded and considered as vital to the Chinese society.

It has been found out that due to the modern complex economic reforms and restructuring of China's industries, more and more women are seen to have been appearing in various industries across China. According to a study this steep rise in the involvement of women across various trade and businesses in China, can be characterized due to the expanding female demand in the Chinese labor market since the year 2000 (Wu \& Zhou, 2015) [3]. This research also verifies 
the statement that the women's employment in trade and businesses across China fulfills the ongoing shortage of labor force in the market which is the driving force behind the success of Chinese industries. Majority of the research work done until now, largely focuses on gender inequality in wage gaps, however, the differential aspect of all these researches done on women employment in trade and businesses across China, significantly misses out on highlighting such low female presence in Chinese trade despite of existing circumstantial evidences stating the role, women in China play in the success of Chinese businesses. This research significantly gives rise to a primary research question mainly being as to what is the cause of such low female presence in the Chinese workforce.

Chinese women as a subject of "non preference" by their employers in China can be regarded as being a symbol of pessimism in today's 21 st century corporate China. This is indicative from what Xiaoping (2000) [2] says, that Chinese women workforce doesn't create an environment of optimism among those highly ranked within the work environment, and has led to a lower economic status for women as many of them are losing their highly paid work positions. Women workforce in today's China can clearly be seen as not enjoying the benefits of those high paid jobs since the reformation of the private enterprises. The gap in choosing to employ more male labor force over female as an option is seemingly increasing the way globalized China does trade today. Therefore, a detailed understanding of Chinese employers reluctance to hire women employees is highly crucial and moreover, a necessity in determining the nature of relationships that exist between the women employed and the rate of success for the businesses, helps this study to compute the causes of such reluctance shared by Chinese businesses against women employment.

Gender inequality in China against women can said to be of patriarchal in nature because of China's work life balance culture. Since 2002 women's income in full time paid jobs have dropped down to $36.9 \%$ as compared to $39.8 \%$ in the previous decade, which can be attributed to rising gender gap in employment as stated by (Ding, Dong \& Li, 2009) [4]. This statement points out towards the existing inequality which is prevailing in modern Chinese businesses. People in China have been traditionally seen to be having a dislike towards women earning more than their male counterparts, and this trend can be seen existing in modern times too. Women in China constantly come under pressure from their family members at home and from their fellow male workers at work, against working in good jobs and receiving higher salaries than men. Thus it is highly remarkable to determine the rate of such discrimination against Chinese working women by their families, male workers, and most probably by their employers, which helps to establish the extent of it.

\section{Literature Review}

Women presence across businesses in China is seemingly declining in the 21st century, as it is experiencing sharp reduction in the numbers. Subsequent statistics 
reported by the International Labor Organization indicates that there has been nine percentage points drop in the women workforce, declining from $73 \%$ in the year 1990 to $64 \%$ in 2014 (Erdenebileg, 2016) [1]. The statistics is quiet shocking which gives a real picture on the current situation about the female labor force in China as it remains under constant debate. These figures are drastically alarming as it poses a threat of extinction of women workers in highly paid jobs from the face of Chinese industries. The statistics gathered from International Labor Organization by (Erdenebileg, 2016) [1] hasn't been discussed further over here, as the information is very basic in nature and however doesn't state any figures indicating the amount of percentage drop in various industries categorically.

Study done on gender and employment in China focused on over $1800 \mathrm{em}$ ployees across 22 retail based companies, to analyze the rate of male and female employment in high paying jobs (Gamble \& Huang, 2015) [5]. Age, marital status, education and job rank were the key variables for the study, which showed a constant down in the trend when it came to assigning women employees to the higher paying positions. The research further yielded quiet disturbing results, as the women workforce where found out to be quiet dissatisfied with their salaries and job ranks when compared with male workforce on a regression scale. Overall figures revealed that only $18.5 \%$ of women among the population of 1800 employees were either working in highly skilled jobs or were having high paying salaries, as compared to $31 \%$ of men working in highly paid and skilled jobs. Based on the results, it indicated that the overall rate of employment of women in highly skilled jobs in the retail sector is comparatively much lower as compared to other sectors in the job market (Gamble \& Huang, 2015) [5], but there is no conclusive figures available in the research regarding the differences between the rate of women employment in retail sector and others.

Research conducted on Chinese women employment in China by Bohong (2000) [6] suggests that women's participation in the Chinese industrial workforce force has been $15.99 \%$ and $10.35 \%$ in secondary and tertiary sectors, respectively. The research looks into the gender analysis through a descriptive analysis of other studies pertaining to the topic, by focusing on women's occupational composition and income as the main factors for the context, when compared to their male dominated workforce. The occupational structure of women against men across various levels of jobs in Chinese businesses viz, technical, clerical and managerial stood to $5.07 \%, 1.30 \%$ and $1.81 \%$ respectively whereas only $1.81 \%$ women were found to be heading some kind of department within those businesses.

A survey with a sample size of 9000 couples in various provinces in China conducted by the "Population Institute of the Chinese Academy of Social Sciences" on the income distribution of between men and women in Chinese businesses, observed that women's income was the lowest for all the provinces as par with men except Guangdong province where women earned 390 yuan (\$60.59) each week as compared to 320 yuan (\$49.71) for men, mainly because 
of Guangdong being an industrial province (Bohong, 2000) [6]. This study lines with the continuing declining trend in the women's workforce and their income in Chinese jobs, however the lack of focus on generating information on different individual Chinese businesses and their numbers, when compared to the women employed in them across various job levels as stated by Bohong (2000) [6] in this research, makes it impossible to compare the resultant outcome of different businesses as far as their success rate is concerned, while having lower female workforce in them, which is being previously mentioned, including only $1.81 \%$ women employee as heads of the businesses.

\subsection{Statistics of Women Employment and Wages in Chinese Firms}

The data estimates by International Labour Organization on women's workforce participation in China, for a period of 26 years indicate that there has been a significant amount of drop in the female staff across various businesses with total number of women working amounting to $73.49 \%$ in the year 1990 (The World Bank, 2016) [7], declining to 63.34\% in the year 2016 (The World bank, 2016) [7]. The report also suggests that the female labor force participation was quiet stable until the year 2001 which saw 70.42\% (The World Bank, 2016) [7] in women workforce presence, while still decreasing, in corporate businesses across China before the down turn in the numbers started to occur. Moreover, the China Statistical Yearbook for 2016 has estimated that around 16,394.9 (National Bureau of Statistics of China, 2016) [8] women are only employed in higher job positions across the main commercial cities in China with the figures stating between the years 1995 to 2015, that the average salaries of the women working in high paid jobs have increased from 5348 yuan (\$834.98) to 62029 yuan (\$9684.59) per month (National Bureau of Statistics of China, 2016) [8]. Surprisingly this number seems very developmental but it is still seemingly low, when compared with the monthly salaries of men working in higher paid jobs which approximately crosses $\$ 12,000$ mark (National Bureau of Statistics of China, 2016) [8].

Evidences to the above estimates can also be found in a study done on women in Chinese business, which agrees to the fact that even though the women employment is becoming a significant part of corporate industries in China, its growth rate has been slow with the numbers only increasing to $2.30 \%$ from 1997 to 2001 (A to Z World Business, 2018) [9], which saw $41 \%$ of the working women in the country (A to Z World Business, 2018) [9]. Further in this study, it highlights the existence of discrimination by the Chinese businesses against women belonging from minority regions, which is directly blamed as the primary cause for such slower employment growth for women when compared to those hailing from primary industrial towns. This study also gives a deeper information by criticizing into the fact that, even though majority of the companies in China claim that women are given equal wages for their hard work, but the women's wages in China approximately account for only $70 \%$ of the men's 
wages (The World Bank, 2016) [7], which is a poor statistics when compared on a global scale. Estimates also indicate that, the women's income has dropped considerably from $28.98 \%$ in 1990 to $0.69 \%$ in 2016 (The World Bank, 2016) [7]. China's traditional employment sector is also supposed to be blamed for such lower women presence in firms, as traditionally China has a record of employing majority of its women population in agriculture related businesses. This scenario is also argued in the same study which confirms China still traditionally employing more women in rural sector which accounts for 85 million, of which $40 \%$ are females (A to Z World Business, 2018) [9], due to which employers in the urban areas still see women with that stereotypic image who are worth for agricultural work only.

\subsection{Statistics of Profitability for Chinese Firms}

Business profitability for firms and companies can be seen declining in the last 26 years. Data collected on the profit growth rate of various firms between 1990 and 2016 have dropped to the lowest figure since 2016, with profits sharply descending to $5.81 \%$ from the high of $12.82 \%$ in 1990 (The World Bank, 2016) [7]. The report suggests that even though the firms domestic credits reached $156.70 \%$ in 2016, from $86.20 \%$ in early 1990's on a GDP scale (The World Bank, 2016), the firms values only remained at 6.07\% in 2016 (The World Bank, 2016) [7]. The contrasting factor is that this figure is drastically lower than previous 20 years figure, with firms value reaching to ever time high of $24.97 \%$ in 1992 and most recently at $15.45 \%$ in 2010 (The World Bank, 2016) [7], which then followed with a constant decline. The firms hard incoming cash accounted for $82.8 \%$ as compared to latest 2016 figure of $68 \%$, stating a wide gap of $14.8 \%$ in financial profits earned in 2016 (The World Bank, 2016) [7] by those firms while considering 11 years of constant stable financial earnings. In a broader context, the figures indicate firms facing a severe depression in their success rate numbers. Existing study on institutions and economic growth in China, emphasize that despite of China's attractive investments by both the foreign and local firms, companies in China are struggling to grow mainly due to shortage in financial capital (Che \& Wang, 2013) [10]. This also aligns with the 2016 data retrieved from the World Bank which highlights the loss in profits the firms across China are experiencing since the 2007 downfall. More interestingly, even the study done on Women's employment and family income inequality during China's economic transition, state that the financial revenues of the firms across Urban China faced a serious decline from $22.5 \%$ in 1989 to $1.37 \%$ in 2002 (Ding et al., 2009, p. 167) [4].

\subsection{Linkages between Women Workforce and Firm Profitability}

It can be clearly seen from the International Labour organization figures that when the women's labor force participation in Chinese businesses went high up in the early 1990's, with $73.49 \%$ being in the year 1990 itself (The World Bank, 
2016) [7], the profit growth for firms were significantly high with a recorded figure of $12.82 \%$ in the same year (The World Bank, 2016) [7]. In contrast to that, the firm profitability decreased while women's participation in businesses decreased, with ILO figures indicating a decrease in profits to $5.81 \%$ in 2016, while $63.34 \%$ women were employed in that year (The World Bank, 2016) [7]. Not only this, but even the firms incoming hard cash as part of their profits also declined since 2010 with a figure amounting to $66.3 \%$ in 2010 as compared to $81.4 \%$ in the previous year (The World Bank, 2016), which constantly fell until reaching 68\% in 2016 (The World Bank, 2016) [7].

All these figures were based on the data collected during a period of 26 years from 1990 to 2016. One of the interesting factor to these statistical numbers is that, even though the firms kept on downsizing the women's workforce in the previous years to $0.69 \%$ in 2016, from the actual $28.98 \%$ in 1990 (The World Bank, 2016) [7], presumably to reduce costs, this step hasn't positively affected the firms profit, instead the firms can be seen suffering losses in their businesses according to the official government reports. Subsequent studies also corroborate with these figures. A study done on gender and work compensation in China's industrial sector indicates that the domestic firms operating in China specially in the industrial sector, face profit disadvantage due to low presence of highly skilled female workers in their companies (Rickne, 2012) [11]. Further to this, another study done on gender dynamics and redundancy in Urban China focusing on economic reforms after the 1990's, points out that redundancy of female workers in the non state owned firms have severely affected the profit rate of those firms at the national economy level (Liu, 2007) [12]. This work also strengthens the data gathered by the World Bank which correlates to the theory, that increased women's participation in businesses generates more profits while their declining numbers bring in huge losses to the firms' profits.

\subsection{Gender Discrimination in Employment against Women}

Prejudice against women employed in high paid jobs in China has been a long issue since the economic reforms post 1990 era. Studies conducted by various researchers across the globe point out towards only one single aspect of it since the late 1990's. It is the discriminatory treatment against women which demoralizes the female workforce participation and thus is hurting the employers' skills investment on them, leading to a damaging impact on the companies and the local economy at large (Rickne, 2012) [11]. Since the reformation of the markets, women have been the most hardly hit gender who have faced $60 \%$ in radically motivated layoffs since the year 1999 (Liu, 2007) [12]. Women in China have been long a subject of the gender category who don't possess any skills according to their families and male colleagues. This is indisputable in a study which suggests that China has been in perception, that lack of talent is a women's forte, blaming the country to be in a state of Confucianism, created by the traditional family beliefs and co-workers (Xiu \& Gunderson, 2012, p. 236) [13]. Subsequent 
studies have blamed the theory of intergenerational co-residence which includes a presence of an elderly family member in Chinese families who restricts the women from her ability to do well paid jobs and earn good money than her husband, or a significant male entity present in the house (Zhou \& Wu, 2015, p. 320) [3]. The perception of the male co-workers regarding women's inability of having proper work skills and lack of talent in them creates an additional constraint to the situation. Investigation to such kind of attitude by male peers at work has been directed towards a presence of oppressive ideologies related to work, which still exists in the 21st century (Long, 2016) [14]. Furthermore, this study discloses that the patriarchal mindset that women have to obey their husbands at home, and men at work should be valued more, has reciprocated since the economic reform after 1990's, which has put China back on the same direction of cultural norms which used to exist before the birth of the Communist party of China and more specifically, The People's Republic of China.

Gender segregation has always been a part of Chinese culture where women in the household earned less salaries than their husbands (Ding et al., 2009, p. 166) [4]. This is evident from a study done by Rickne (2012) [11], which observes that there is a $12 \%$ difference in the wage gap between skilled men and women in Chinese households where both the husband and the wife are highly educated. The study has further found out that the situation of women with medium level of education in a household is even worse with an average of $20 \%$ difference in the wages between the man and the woman (Rickne, 2012) [11]. The study also gives a reference of insights into the wage gap situation by Hellerstein and $\mathrm{Nu}$ emark, stating they established that, highly skilled working women earned 38\% less than their highly skilled male counterparts at work, mainly due to the existing patriarchal mindset of the company bosses. These figures clearly tell the story and visualize the existing discrimination against women in the Chinese patriarchal society at its worst. In fact, it has been observed in a study that discrimination against women by their employers at work accounts for $40 \%$ (Dammert \& Marchand, 2015, p. 250) [15]. Not only this, the discrimination also accounts for $18 \%$ by the male colleagues who don't want their female co-workers to be at some kind of senior executive position inside the company (Gao, Lin and Ma, 2016) [16]. This study conducted on sex discrimination in large multi-national corporations in China reveal a more serious fact, as it further escalates $7 \%$ in the discrimination number by the male peers who don't want their female colleagues to work alongside them (Gao et al., 2016) [16]. This figure instantly brings down the data on discrimination against women at work by their male co-workers in China to a total of $25 \%$ (Gao et al., 2016) [16].

Disagreement regarding family responsibilities among the Chinese households have been sought to be the major characteristic for gender disparities in the labor market for women. This fact is conclusive through a work done on gender based employment and income differences in urban China, suggesting $35 \%$ in discrimination rate faced by household working women from their family 
members(Zhang, Hannum and Wang, 2008) [17]. This could also be considered as a contributing factor behind many married women in China receiving termination notices and changing jobs because of various family conflicts, as the data across the world on the issue suggests. It can therefore be argued through the statistical figures regarding the rate of discrimination against employment of women in China by various sections of the society, that we see such low ratio of women employed in Chinese businesses across the nation and their numbers are systematically declining.

\section{Method}

For this paper, correlation method of approach has been adopted to establish the desired relationships between firm profitability rates and the female labor force participation rates along with the female income rates and the female employment discrimination rates. Correlation method usually yields quantitative results to determine relationships through regression models for analytics (Thompson, Diamond, Mcwilliam, Snyder and Snyder, 2005) [18]. Henceforth, the multiple linear regression model as studied to work out the correlation between two variables in order to determine the cause and effect (Uyanik \& Güler, 2013) [19], has been applied to this study. The multiple linear regression has been performed on the dataset gathered from the World Bank for a period of 26 years between 1990-2016 displayed in Table 1. A causal analysis on the income inequality in China after economic reforms uses time series data to review the existing income disparities (Chen, Glasmeier, Zhang and Shao, 2016) [20].

This research has used the time series data to establish those relationships as to whether growing firm profits across China can be directly said to be linked due to increased female participation in jobs, and as well as whether it increases the women's income in jobs and consequently the rate of discrimination in employment faced by them. As this research is mainly concentrated on the data gathered for 26 years, the use of time series data has been deemed suitable in this case as utilized in a study demonstrating that time series data is the collection of organized statistics gathered over time (Esling \& Agon, 2012, p. 1) [21]. Multiple linear regression has been predominantly selected in order to have multiple independent variables so as to produce meaningful empirical results with expected significant values to the statistical measures in the regression model, and is corresponding to the fact stated by Jones (1972) [22], that the multiple linear regression analysis can have any number of independent variables to delineate its association with the geologic variable.

In this research, one dependent variable has been drawn along with three independent variables. Firm profitability has been assumed as the dependent variable, as the research hypothetically relies on the common notion prompted from the review of other literatures on topic, that increased women's participation has significant impacts on the success of the Chinese firms and that women play a principal role across businesses in China. 
Table 1. Data exhibit for firm profitability, female labor force participation, their rate of income, and rate of discrimination against women at work between 1990-2016.

\begin{tabular}{|c|c|c|c|c|}
\hline Year & $\begin{array}{l}\text { Firm Profitability } \\
\text { (Overall \%) }\end{array}$ & $\begin{array}{c}\text { Female Labor Force } \\
\text { Participation (\%) }\end{array}$ & $\begin{array}{l}\text { Female Income } \\
(\%)\end{array}$ & $\begin{array}{l}\text { Rate of Employment } \\
\text { Discrimination (\%) }\end{array}$ \\
\hline 1990 & 73.4940033 & 12.8286664 & 28.98945597 & 34.80000114 \\
\hline 1991 & 73.36799622 & 11.92621998 & 27.51542587 & 35.899999962 \\
\hline 1992 & 73.24700165 & 24.9762865 & 26.55589872 & 36.599998847 \\
\hline 1993 & 73.12200165 & 23.40050816 & 25.77788991 & 37.30000114 \\
\hline 1994 & 72.97100067 & 12.51495038 & 24.99667788 & 38.10000038 \\
\hline 1995 & 72.77999878 & 14.33146817 & 23.96667834 & 39 \\
\hline 1996 & 72.5530014 & 9.336346267 & 22.56547432 & 40 \\
\hline 1997 & 72.28500366 & 3.819793421 & 21.66699176 & 41.20000076 \\
\hline 1998 & 71.97399902 & 6.508279881 & 20.45534335 & 42.10000038 \\
\hline 1999 & 71.625 & 4.85723931 & 19.78723378 & 43.19999886 \\
\hline 2000 & 71.24199677 & 5.701587405 & 18.99163654 & 45.29999924 \\
\hline 2001 & 70.42500305 & 16.42171553 & 17.88177778 & 46.79999924 \\
\hline 2002 & 69.53600311 & 10.40438013 & 16.99966671 & 48.19999886 \\
\hline 2003 & 68.61299896 & 19.88078699 & 15.45699951 & 49.69999886 \\
\hline 2004 & 67.71800232 & 16.17931466 & 14.33899981 & 51.89999771 \\
\hline 2005 & 66.90000153 & 9.286463889 & 13.60000038 & 53.69999886 \\
\hline 2006 & 66.16200256 & 13.69327857 & 9.300000191 & 54.80000114 \\
\hline 2007 & 65.51200104 & 15.61459988 & 8.399999619 & 55.79999924 \\
\hline 2008 & 64.91999817 & 12.62553319 & 8.399999619 & 56.69999886 \\
\hline 2009 & 64.33300018 & 19.45995706 & 4.900000095 & 57.40000153 \\
\hline 2010 & 63.72000122 & 15.45604476 & 4.5 & 58.20000076 \\
\hline 2011 & 63.74300003 & 9.253574144 & 3.599999905 & 59.60000038 \\
\hline 2012 & 63.75799942 & 7.179757737 & 2.099999905 & 62.09999847 \\
\hline 2013 & 63.77899933 & 9.090571184 & 1.8999999976 & 65.70000076 \\
\hline 2014 & 63.72800064 & 7.163979749 & 0.8999999976 & 69.10000038 \\
\hline 2015 & 63.58000183 & 6.173034113 & 0.699999988 & 73.89999962 \\
\hline 2016 & 63.34899902 & 5.818007266 & 0.6999999988 & 75.20000076 \\
\hline
\end{tabular}

Note: Data on firm profitability, female labor force participation, female income \& employment discrimination from The World Bank (2016).

Rate of female labor force participation, female income and discrimination against women in employment has formed as independent variables in this research, with female labor participation being the primary independent variable in consideration which is a determinant to simplify the unknown relationship between women's presence across Chinese businesses and the success rate of those businesses. Due to this factor being the primary nature of this study, the work done on the relationship between foreign trade and regional disparities in 
China in the post reform era has been considered as primary, which uses correlation coefficient as an indicator to demonstrate the linear relationship between two variables through scatter diagram (Zhang \& Jiang, 2016, p. 60) [23]. Due to lack of suitable data on individual firms, it has been unsuccessful for this research to analyze the datasets of firm wise annual profitability rates and the impacts on them due to low presence of female workforce in those individual firms, female staff salaries and the annual rate of employment discrimination faced by women in each of the individual firms.

The correlation coefficient model which follows after regression model, has been implemented. The following datasets for the correlation coefficient model can be found in Table 3, stating the firm profitability and female labor force participation rates between the years 1990-2016, which has been selected from the World Bank (2016) [7] datasets in Table 1. The idea behind working out the correlation coefficient using scatter diagram is to substantiate it with the regression model and that both of them yield same results in order to verify their authenticity. Table 1 shows the datasets of firm profitability, female labor force participation, rate of income and rate of women discrimination at work gathered from the World Bank for the period 1990-2016.

The firm profitability dependent variable data has been primarily considered from the annual percentage growth rate in terms of amount of financial credits earned by the firms in China between 1990-2016. The data on independent variable, which is the women's participation rate across Chinese firms, indicate the rate of female labor force participation between 1990-2016. The data for the two other independent variables including the female income rate and their rate of discrimination in employment also states the figures between 1990-2016. Further, the regression analysis establishes the impact of firm profitability on the women's rate of income and consequently the rate of discrimination faced by them. Table 2 lays out the regression model adopted for this research indicating firm profitability rate as the dependent variable and female labor force participation, female income and female employment discrimination rate as three independent variables which forms as the backbone for this investigation.

For the purpose of this research, the values of adjusted $\mathrm{r}^{2}$, the $\mathrm{p}$-value and the $\mathrm{t}$-stat has only been considered as primary statistical measures for analysis in this case, as traditional regression modeling methods highly emphasize on these values being as the focal point of all statistical literature studies (Bagos \& Adam, 2015, p. 680) [24]. These measures therefore, have mainly formed as the basis for the empirical interpretation of the relationship between the dependent variable and the independent variables, i.e. the firm profitability and the female labor force participation, female income and gender discrimination in employment for women.

As this study, aims to rationalize the major issue of low presence of women in employment in China and that whether their presence has any significant impact on the firm profitability, the female labor force participation has also formed as the primary independent variable in this study as mentioned earlier in the methods, and its presumed significant linear relationship with the firm profitability 
has been graphically underlined in Figure 1 using a scattered diagram to demonstrate its correlation coefficient.

\section{Analysis and Discussion of Results}

The analysis to the study of low presence of women in Chinese businesses has produced quiet interesting but contemplating results which corroborates with the existing presumptions of this research. The analysis of the relationship between firm profitability and female labor force participation with the regression model can be seen confirming the prevailing rationale for such low presence of women in employment across China, evidently signifying the nature of relationship among them. Subsequently, the use of correlation coefficient model with a scatter diagram has provided with critical visualization regarding the direction of the course of relationship between the firm profitability and the female labor force participation in Chinese businesses. The analysis of the regression model along with the scatter diagram for correlation coefficient together, to determine the relationship between firm profitability and female labor force participation, especially has supported to correctively balance the quantifiable results analogously.

The model has generated key observations to the impacts of firm profits on female income and their characteristic relationships among them, which has helped in to having deeper insights into the lower women workforce presence across Chinese businesses which is the primary subject matter in concern. The regression model has also been successful in analyzing and understanding the current pattern of employment discrimination against women by employers in China and its variable effect on the firm profitability. The analysis of the regression model interprets the primary observations for the aspects limited to the relationship between firm profitability and female labor force participation, the relationship between firm profitability and female income, and finally the firm profitability and the rate of employment discrimination faced by women across firms in China, all between the years 1990-2016, and follows the next segment of this empirical results section. Table 2 depicts the regression model summary for statistical assessment of the dependent and independent variables i.e. the firm profitability vs. female labor force participation, female income \& rate of employment discrimination.

Table 2. Regression statistics model summary for firm profitability and female labor force participation, female income and rate of employment discrimination.

\begin{tabular}{cccccccc}
\hline Multiple R & 0.9897020283 & & df & SS & MS & F & Significance F \\
R Square & 0.9795101048 & & & & & & \\
Adjusted R Square & 0.9768375098 & Regression & 3 & 398.8639584 & 132.9546528 & 366.5015076 & 0 \\
Standard Error & 0.6023014204 & Residual & 23 & 8.343641024 & 0.3627670011 & & \\
Observations & 27 & Total & 26 & 407.2075994 & & & Upper 95\% \\
\hline & Coefficients & Standard Error & t Stat & P-value & Lower 95\% & 68.5652622 \\
\hline Firm Profitability & 62.36882426 & 2.995390803 & 20.82159837 & 0 & 56.17238631 &
\end{tabular}




\section{Continued}

\begin{tabular}{ccccccc}
\hline $\begin{array}{c}\text { Female labor force } \\
\text { participation }\end{array}$ & -0.06237494879 & 0.02245963078 & -2.777202769 & -0.01071615331 & -0.1088362347 & -0.01591366292 \\
$\begin{array}{c}\text { Female Income } \\
\begin{array}{c}\text { Rate of employment } \\
\text { discrimination }\end{array}\end{array}$ & -0.4347482789 & 0.05255985355 & -8.271489541 & -0.00000002407954369 & 0.3260199385 & 0.5434766193 \\
\hline
\end{tabular}

Note: Multiple linear regression analysis over here only examines the significance of the t-stat, $\mathrm{p}$-values and adjusted $\mathrm{r}^{2}$ only which has been taken into consideration as the primary base statistical measures for analyzing the correlation between the dependent $\&$ the independent variables.

\subsection{Correlation between Firm Profitability and Female Labor Force Participation}

Theories to the regression model state that value for t-stat is significant when the number is $>$ than 2.0 irrespective of being positive or negative. The $t$-stat values for female labor force participation can be observed in the analysis to this study, as having a value of -2.777 which is quiet significant. The significance of p-value occurs when the score is <than 0.05 irrespective of positive or negative, which corresponds to the $\mathrm{p}$ value for this study amounting to -0.01 . The value significance of both the $t$-stat and $p$-value indicates a strong significance between the firm profitability and female labor force participation. Conclusive evidences prove that these two statistical measures are the basis for testing the hypothesis of the effects of the independent variable on the dependent variable in concern (Mason \& Perreault, 1991, p. 268) [25]. The regression model indicates that the firm profitability rate is directly dependent on the rate of female labor force participation, and that any changes to the percentage rate in the female labor force in Chinese firms will subsequently bring in critical changes to the firm profitability.

The World Bank (2016) [7] data analysis on firm profitability and female labor force participation for the period between 1990-2016 suggests that, as the female labor force participation decreased, the firm profits also saw a huge decline. Parallel to this, the data for the firm profitability and female labor force participation for the period between 1990-2016 measured on coefficient scale, also yielded identical results representing a similar trend. The results are also in line with the previously described study of Rickne (2012) [11], which found out similar outcome explaining that domestic firms in China faced profit disadvantages due to low female staff in their organizations. The earlier study by Liu (2007) [12] also observed similar outcomes stating that the redundancy in women workforce post 1990 market reforms in urban China, have severely affected the profit rates of non state operated firms. It can be adjudged from the results which indicate towards a crucial element of need for women presence and their contribution to the success of firms in China. Corresponding studies support this observation stating that women's presence in employment raised the economic activity level of Chinese firms to 87\% in the 1980's (Zhang et al., 2008, p. 1533) [17]. Figure 1 shows the scatter diagram highlighting the relationship between firm profitability and the female labor force participation. 


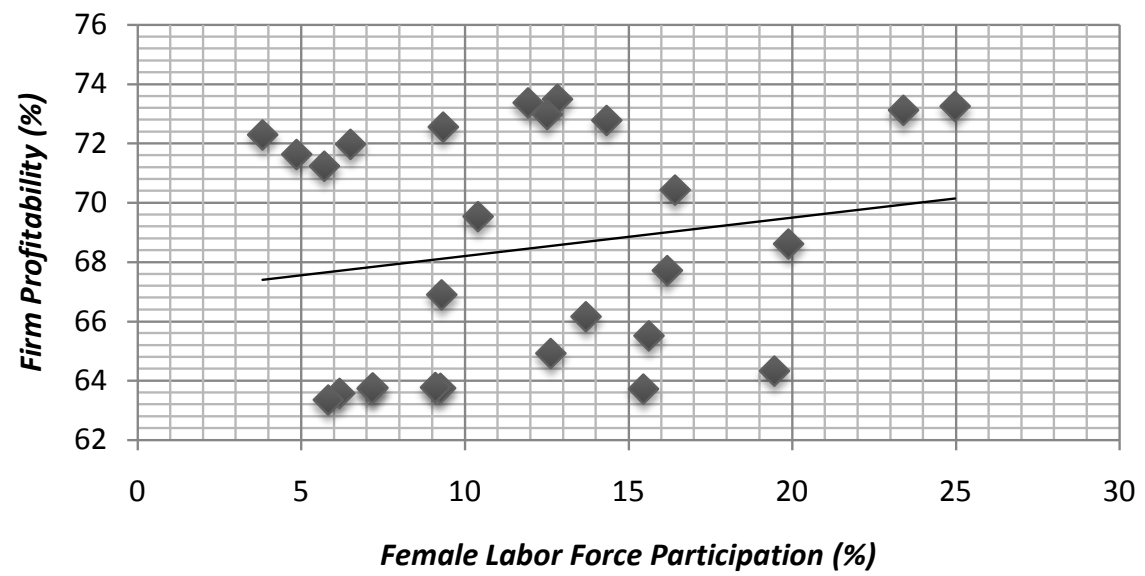

Figure 1. Scatter diagram representing relationship between firm profitability and female labor force participation. Note: Negative linear relationship between firm profitability \& female labor force participation has been represented through the use of a scatter plot with the help of the data gathered for the period between 1990-2016 from The World Bank (2016).

The Correlation Coefficient-Correlation coefficients are related to stronger or weaker values indicating either a positive or a negative linear relationship between the dependent and the independent variables. The correlation coefficient model produced a score of 0.185009353 denoting a weaker measurement for the correlation coefficient for female labor force participation. There seems to be negative relationship between firm profitability and female labor force participation rate on the coefficient scale. The firm profitability can be suggested to decrease if the female labor force participation decreases as contemplated in a similar work, which studies linear relationship between "predicted value and observed valued" stating that, as there is a decrease in the predicted value, the observed value also decreases along side, thus depicting a weaker correlation between them (ASQ's Quality Management Division 2002) [26]. Table 3 shows the correlation coefficient summary for firm profitability and female labor force participation for the period 1990-2016.

Table 3. Correlation coefficient model for firm profitability and female labor force participation (1990-2016).

\begin{tabular}{ccc}
\hline Firm Profitability (\%) & Female Labor Force Participation (\%) & Correlation Coefficient \\
\hline 73.4940033 & 12.8286664 & 0.185009353 \\
73.36799622 & 11.92621998 & \\
73.24700165 & 24.9762865 & \\
73.12200165 & 23.40050816 & \\
72.97100067 & 12.51495038 & \\
72.77999878 & 14.33146817 & \\
72.5530014 & 9.336346267 & \\
72.28500366 & 3.819793421 & \\
\hline
\end{tabular}




\section{Continued}

\begin{tabular}{cl}
\hline 71.97399902 & 6.508279881 \\
71.625 & 4.85723931 \\
71.24199677 & 5.701587405 \\
70.42500305 & 16.42171553 \\
69.53600311 & 10.40438013 \\
68.61299896 & 19.88078699 \\
67.71800232 & 16.17931466 \\
66.90000153 & 9.286463889 \\
66.16200256 & 13.69327857 \\
65.51200104 & 15.61459988 \\
64.91999817 & 12.62553319 \\
64.33300018 & 19.45995706 \\
63.72000122 & 15.45604476 \\
63.74300003 & 9.253574144 \\
63.75799942 & 7.179757737 \\
63.77899933 & 9.090571184 \\
63.72800064 & 7.163979749 \\
63.58000183 & 6.173034113 \\
63.34899902 & 5.818007266 \\
\hline
\end{tabular}

Note: Correlation Coefficient represented over here only estimates the linear relationship between firm profitability \& female labor force participation rates from the data gathered from The World Bank (2016).

\subsection{Correlation between Firm Profitability and Female Income}

The relationship between firm profitability and female income can be seen to be statistically significant which produced a t-stat score of -8.271 on regression model which is $>2.0$ while the $\mathrm{p}$-value constituted to -0.0000000240 conforming to the standardized measure for $\mathrm{p}$ which is $<$ than 0.05 . Further, the correlation coefficient produced a measure of 0.98576548 on the scale. It can be observed from these correlation coefficient scores that firm profitability and female income are positively related to each other, and that as and if, the female income decreases, the firm profitability also decreases which could be seen happening in the recent years since the mid 2000's. The correlation outcome can be seen to have similarities with the discussed study of Gamble \& Huang (2015) [5], expressing the dissatisfaction of the female employees across 22 different retail firms, for being paid so low wages, which could be denoted to the decrease in firm profitability mainly due to lack of motivation to work by those women because of the low wage issue. It is purely feasible to state that there is a strong positive linear relationship between firm profitability and female income, and that female income trend whether towards negative or positive, can have variable impact on the firm profitability. The analysis can be deemed to be true over a consideration of a study by Shu (2005) [27] ascertaining that firm profits in China are directly influenced by the variable levels in the rate of female income, indicating the significance of women's income in jobs on deciding the growth 
and profit accumulation by the firms. Kim (2013) [28] also drives the focus towards the lower productivity and profit rates of firms as a causal effect of decrease in the female income. This confirms the analysis on the data for firm profitability and female income between 1990-2016, underlining the downward pattern of firm profitability because of downfall in the female income. Figure 2 displays the graphical representation of the resultant impact of decline in the female income on the firm profitability by highlighting the relationship between firm profitability and female income.

The work of Bohong (2000) [6] mentioned in this research also seems to be coexisting with the results of this study stating the women's income to be the least among all the Chinese provinces, which ascertains the profit loss being faced by firms due to low female income wages. Also the previously stated analysis in A to Z World Business (2018) [9] which indicated women's income being $70 \%$ of the total men's income, straightens with this effect and clearly gives a realization of the negative impacts on firm profitability due to monumental differences in female income as par with men's income. As it can be seen that, as the female income rates have sharply declined in the past 26 years up until 2016, so did the firm profits too, which validates the analysis for the presence of a strong correlation between the two.

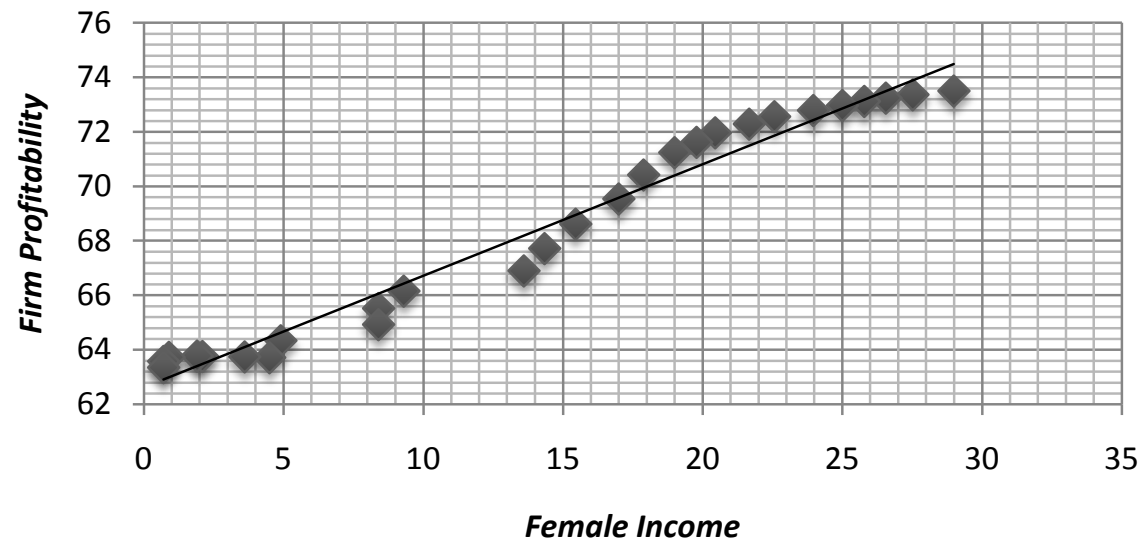

Figure 2. Relationship between firm profitability and female income. Note: Inverse relationship between firm profitability \& female income has been represented through the use of a scatter plot with the help of the data gathered between the period 1990-2016 from The World Bank (2016).

\subsection{Correlation between Firm Profitability and Women's Employment Discrimination}

There seems to be a significant relationship between firm profitability and employment discrimination against women as $\mathrm{t}$-stat and $\mathrm{p}$-values, both seem to be statistically significant and having a strong negative linear relationship among them on the correlation coefficient scale with a measure of -0.9498661 . The $\mathrm{t}$-stat and the $\mathrm{p}$-value for the rate of employment discrimination amounts to a score of 2.2933 and 0.021 respectively, which is well within the limit of the statistical measures of regression in concern to this study. It can be analyzed through the 
correlation coefficient that, as the discrimination against women in employment increases, the firm profitability can be said to go down and vice versa. Figure 3 highlights the relationship between firm profitability and Women's employment discrimination through the use of a scatter plot.

The above statement clearly indicates that firms in China lose a significant portion of their profits due to their bias against women in the jobs which are done by their male counterparts, thus ignoring an essential pool of skilled women workers who could have contributed to the firms intellectual capabilities. There is a homogeneity to this statement from what Burnett (2010) [29] explains, that as the downfall in Chinese businesses occur, its main cause can be denoted towards the biased mindsets of Chinese employers to hire women workers on the grounds that women are less capable, both physically and mentally than men, to do the same level of job.

The results in this study on the employment discrimination faced by women aligns with the work of Rickne (2012) [11] which observed that the lack of investments done by firms on women's hiring and skills are contributing to the financial damages incurred by the companies and to the local economy. Not limited to this, the study of Xiu \& Gunderson (2012) [13] are also in resemblance to the results of this research, where they identified that the co-workers at work perceive women to be lacking in skills and talents. The presence of oppressive ideologies at work as stated by Long (2016) [14] in her study, also justifies the existing discrimination happening against women in employment which is hampering the growth of the firms. The observations in this study on loss in firm profitability as a direct result of employment discrimination against women, is clearly directed towards the study of Dammert \& Marchand (2015) [15], and Gao et al. (2016) [16], which revealed $40 \%$ in discrimination rate by the employers and a total of $25 \%$ by male peers at work. Evidence to the same and for this study also justifies this accuracy through an earlier cited work done by Liu (2007) [12],

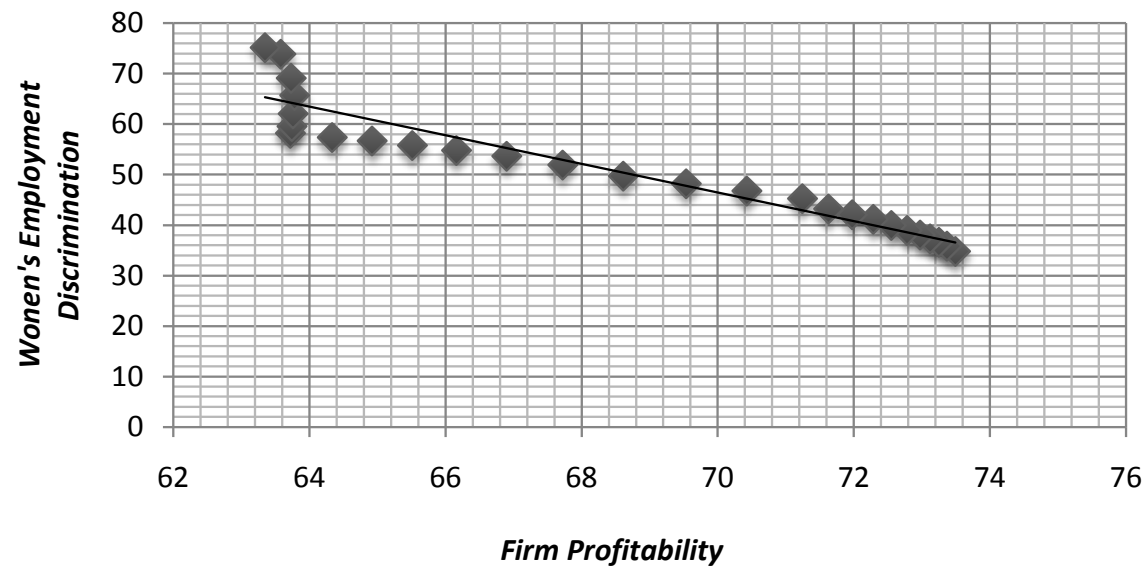

Figure 3. Relationship between firm profitability and women's employment discrimination. Note: Positive linear relationship between firm profitability \& women's employment discrimination has been represented through the use of a scatter plot with the help of the data gathered for the period between 1990-2016 from The World Bank (2016). 


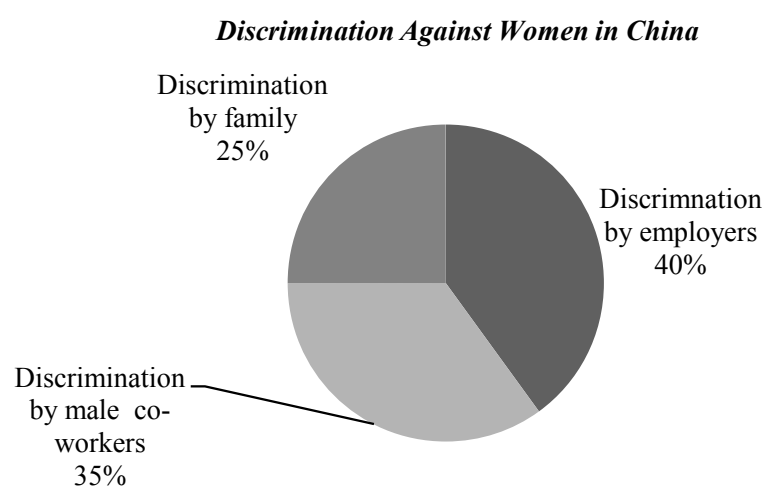

Figure 4. Pie Chart categorically displaying the rate of employment discrimination faced by women from their employers By Dammert and Marchanf (2015), employment discrimination faced by women from male co-workers by Gao et al. (2016), employment discrimination faced by women from family in households by Zhang et al. (2008).

stating that women being the victims of radically motivated discrimination in employment accounted for $60 \%$ since the year 1999 , as previously mentioned in this research. Percentage rate of discrimination against women in China has been depicted above with the help of a pie chart in Figure 4.

\subsection{Explanation to the Adjusted $\mathrm{r}^{2}$}

The regression model in the Table 2, previously came out with a score of 0.976 for the adjusted $\mathrm{r}^{2}$. It indicates $97 \%$ of variation in firm profitability can be explained by variations in female labor force participation, female income and employment discrimination, taking into account of the size of the sample and number of independent variables this study has looked into. This clearly reflects a strong relationship between all these variables. Studies show adjusted $r^{2}$ in consideration when predicting the total variation on a dependent variable as a result of variations in the number of individual independent variables taken into account to a study (Nathans, Oswald and Nimon, 2012) [30]. In respect to this, it can be suggested from the observations that $97 \%$ of the disparities in firm profitability occurs due to the resultant changes in the female labor force participation rate, the female income rate and the rate of employment discrimination faced by women in the corporate firms. Any changes in female labor force participation, female income and employment discrimination, whether increasing or decreasing, affects the firm profitability rates in a negative or positive manner.

\subsection{Future Predictions}

Given all the current circumstances in consideration for all the independent variables, if this pattern tends to continue in the future, based on the regression model, the firm profitability is observed to go down to $62.70 \%$ while considering the female labor force participation after 5 years, and if female income gradually goes down to a rate of $0.59 \%$ and the employment discrimination against women increases to a rate of $76.20 \%$. Table 4 shows the equation table for future prediction in firm profitability based on female labor force participation in next 5 years 
Table 4. Prediction for firm profitability if female labor force participation $=5$ (in years), female income $=0.59 \%$ and employment discrimination $=76.20 \%$.

\begin{tabular}{c}
$62.36+(-0.0623) \times 5$ years $+(-0.43) \times 0.59+0.012 \times 76.20$ \\
$62.70 \%$ \\
\hline
\end{tabular}

Note: The future prediction for firm profitability over here has been calculated based on female labor force participation in 5 years time and on the estimated rate of decline in female income and increase in rate of employment discrimination against women. The predictions are based on the regression model where the coefficients for female labor force participation, female income \& employment discrimination has been taken into consideration.

with a predicted fall in the female income and rise in employment discrimination against women in China. Subsequent research also suggests similar possibilities. Evidence to this can be found in a study, which proposes a steep decline in the firms' profits if the women workforce participation estimates see a future reduction in numbers along with low female income and an increased discrimination against women while seeking employment (Shen \& Lin, 2009, p. 455) [31].

\section{Conclusion and Recommendations}

This study has tried to highlight on the issue of lower women presence in Chinese jobs through an analysis into the characteristics of female labor force participation, women's rate of income in the jobs and the nature of employment discrimination being faced by them in today's 21 st century corporate China. It has looked into the patterns of female labor force participation rate in Chinese firms, analyzed the statistics of female income rate and its current trend, and also examined the condition of employment discrimination faced by women. Multiple linear regression analysis was considered as deemed to study these various aspects in concern to the study of lower female presence in Chinese firms. The regression model disclosed some significant results into the study and also statistically predicted some important future outcomes.

\subsection{Recommendations}

Future research on the topic should focus on accumulating datasets consisting of annual firm wise data on female labor force participation. Comprehensive changes to the labor laws need to be formulated by the government in collaboration with the private firms which oversees higher female participation rates in jobs. This is supported by Song (2003) [32] who calls for transitional changes to the demand side policy of the Chinese government to create more employment for women and boost their participation in local jobs. This study in fact strongly calls for the need of transparency laws to be developed by the government to make sure that Chinese firms encourage higher female participation in their workforce, and that it is strictly followed in accordance to the law by the private enterprises.

Firms across China need to welcome exhaustive changes in wage policies for women in their respective organizations and encourage themselves to develop an 
attitude of equal pay among both male and female employees. Perhaps, firms need to increase their human capital on women in order for them to raise female staff salaries (Zhang \& Dong, 2008, p. 111) [33] and assign their women staff on projects which looks into improving their skills which ultimately raises their salaries (Wei, Yang, Liu, Wu and Xiang, 2013) [34]. Also academicians around the world and various research institutions need to look into the individual income of women across all Chinese domestic firms while conducting further research on this issue and give valuable insights into their effects on firm profitability, whether negative or positive.

In relation to the annual rate of discrimination faced by women at workplace and in household in China, existing research on sex discrimination in employment against women exerts the focus for an extensive data collection on individual firms to study its depth (Gao et al., 2016, p. 700) [16], and future researchers should consider this factor while gathering statistics for their study.

As Bulger (2000) [35] has cited the urgency for Chinese government to enforce the strategies of equal employment rights for women on Chinese firms, through the creation of new social reforms for women at workplace, this research similarly stresses on the need for both the government and private firms in China to adopt socialistic policies of Chairman Mao which gave equal opportunity and higher powers to women at work, and also while choosing their future careers in the pre-reform era, a resultant of which can lead to an equilibrium among men and women within the workplace in this 21 st century corporate China.

\subsection{Conclusion}

First, the declining women's participation in Chinese jobs has been found to be directly responsible for declining firm profits as they both share a weak relationship among them, even though they had a value significance on regression analysis. It has been noted through this research that, increased labor force participation for women in Chinese businesses has a positive effect on raising the profits for the firms, which can be witnessed as contradictory in the case of women in China. The findings can be denoted to have severe implications on the current government policies which control the private sector firms. The current communist party backed government in China claims to provide employment to millions of educated Chinese women while keeping up with the goal of pre-economic reform era of Chairman Mao, to give powers to women in jobs, which this study has found to be conflicting. According to Knight (2016) [36] existing evidence on labor market reporting clarifies this statement, by highlighting on the false representations made by Chinese government on female participation rate in mainstream labor force in China and argues that numerous findings to this aspect proves it to be consistent. Lack of available firm wise data on women's participation in the individual firms have severely hampered the quality of the results which couldn't further look into the number of female employees actually working inside each of those firms, which could have detailed 
the findings.

Second, the regression model also came up with a strong significance between firm profitability and female income with the correlation coefficient measure highlighting the positive linear relationship among them, which observed that the decline in female income can also be said to be having damaging impact on the firm profits in China. In contrary to that, incremental female income helps in increasing the firm profitability to greater heights. Any substantial evidence on female income in the individual firms across China would have helped in having a detailed understanding about the nature of this positive linear relationship between it and the individual firms. Firms nationwide in China can have a drastic impact on them due to this low wage policy against women at work, as it is evident from this study, that women employees' loose motivation at work because of getting paid less while their male counterparts earn more than them. According to Liu (2011) [37] the introduction of "Xia gang" policy of cutting down on female wages have majorly contributed to decline of profit shares for non state owned enterprises. Review on other literatures on this aspect has also expressed similar concerns in this study.

Third, negative linear relationship was found between firm profitability and employment discrimination faced by women in China, which concluded that there is an increasing discrimination against women in employment since more than last two decades which is being directly blamed for the firms loosing profits in China. It can be agreed that if the discrimination against women in employment ceases to occur, the firms across China can experience a growth in their profit levels. Discrimination against women in employment in China is widespread and can be seen occurring both at women's workplace and as well as in the family households. The annual rate of employment discrimination faced by women in individual firms in the last two decades couldn't be assessed however, mainly due to insufficient information on the subject matter which could have helped in looking deeper into this discriminatory behavioral attitudes perceived by women's employers and male co-workers in each of the individual firms and the nature of its effects on the firm profitability.

Future predictions also suggested a further decline in firm profitability to $62.70 \%$ after 5 years if the female labor force participation and female income continues to drop at a similar estimated rate and if the employment discrimination against women further increases according to the stated estimation.

\section{Conflicts of Interest}

The author declares no conflicts of interest regarding the publication of this paper.

\section{References}

[1] Erdenebileg, Z. (2016) Holding up Half the Sky? Assessing the Current State of Female Employment in China. China Business Review, 1, 1.

[2] Xiaoping, W. (2000) The Market Economy, Gender Equality, and Women's Development from the Viewpoint of Women's Employment. Chinese Education and 
Society, 33, 44-54. https://doi.org/10.2753/CED1061-1932330644

[3] Wu, Y. and Zhou, D. (2015) Women's Labor Force Participation in Urban China, 1990-2010. Chinese Sociological Review, 47, 314-342.

https://doi.org/10.1080/21620555.2015.1036234

[4] Ding, S., Dong, X.Y. and Li, S. (2009) Women's Employment and Family Income Inequality during China's Economic Transition. Feminist Economics, 15, 163-190. https://doi.org/10.1080/13545700802526541

[5] Gamble, J. and Huang, Q. (2015) Social Expectations, Gender and Job Satisfaction: Front-Line Employees in China's Retail Sector. Human Resources Management Journal, 25, 331-347. https://doi.org/10.1111/1748-8583.12066

[6] Bohong, L. (2000) Chinese Women's Employment. Chinese Education and Society, 33, 73-93. https://doi.org/10.2753/CED1061-1932330273

[7] The World Bank Group. (2016) Databank. http://databank.worldbank.org/data/home.aspx

[8] National Bureau of Statistics of China, China Statistical Yearbook. (2016) Average Wage of Employed Persons in Urban Units and Related Indices. China Statistics Press. http://www.stats.gov.cn/tjsj/ndsj/2016/indexeh.htm

[9] A to Z World Business. China: Women in Business. http://www.atozworldbusiness.com.librarydb.northwood.edu:2048/\#mode=country \&regionId $=32 \&$ uri $=$ country-content\&nid $=20.33 \&$ key=women-business

[10] Che, Y. and Wang, D.T. (2013) Multinationals, Institutions and Economic Growth in China. Asian Economic Journal, 27, 1-16. https://doi.org/10.1111/asej.12001

[11] Rickne, J. (2012) Gender and Work Compensation in China's Industrial Sector. Review of Income and Wealth, 58, 307-329. https://doi.org/10.1111/j.1475-4991.2011.00489.x

[12] Liu, J. (2007) Gender Dynamics and Redundancy in Urban China. Feminist Economics, 13, 125-158. https://doi.org/10.1080/13545700701445322

[13] Xiu, L. and Gunderson, M. (2013) Gender Earnings Differences in China: Base Pay, Performance Pay, and Total Pay. Cotemporary Economic Policy, 31, 235-254. https://doi.org/10.1111/j.1465-7287.2011.00307.x

[14] Long, Z. (2016) A Feminist Ventriloquial Analysis of Hao Gongzuo (“Good work”): Politicizing Chinese Post-1980s Women’s Meanings of Work. Women’s Studies in Communication, 39, 422-441. https://doi.org/10.1080/07491409.2016.1224991

[15] Dammert, A.C. and Marchand, B.U. (2015) Privatization in China: Technology and Gender in the Manufacturing Sector. Contemporary Economic Policy, 33, 250-264. https://doi.org/10.1111/coep.12071

[16] Gao, H., Lin, Y. and Ma, Y. (2016) Sex Discrimination and Female Top Managers: Evidence from China. Journal of Business Ethics, 138, 683-702. https://doi.org/10.1007/s10551-015-2892-x

[17] Zhang, Y., Hannum, E. and Wang, M. (2008) Gender-Based Employment and Income Differences in Urban China: Considering the Contributions of Marriage and Parenthood. Social Forces, 86, 1529-1560. https://doi.org/10.1353/sof.0.0035

[18] Thompson, B., Diamond, K.E., Mcwilliam, R., Snyder, P. and Snyder, S.W. (2005) Evaluating the Quality of Evidence from Correlational Research for Evidence-Based Practice. Council for Exceptional Children, 71, 181-194. https://doi.org/10.1177/001440290507100204

[19] Uyanik, G.K. and Güler, N. (2013) A Study on Multiple Linear Regression Analysis. Procedia-Social and Behavioral Sciences, 106, 234-240. 
https://doi.org/10.1016/j.sbspro.2013.12.027

[20] Chen, G., Glasmeier, A.K., Zhang, M. and Shao, Y. (2016) Urbanization and Income Inequality in Post-Reform China: A Causal Analysis Based on Time Series Data. PLoS ONE, 11, e0158826. https://doi.org/10.1371/journal.pone.0158826

[21] Esling, P. and Agon, C. (2012) Time Series Data Mining. ACM Computing Surveys, 45, 1-34. https://doi.org/10.1145/2379776.2379788

[22] Jones, T.A. (1972) Multiple Regression with Correlated Independent Variables. Journal of the International Association for Mathematical Geology, 4, 203-218. https://doi.org/10.1007/BF02311718

[23] Zhang, Q. and Jiang, Y. (2016) On the Relationship between Foreign Trade and Regional Disparity in China in the Post-Reform Era. Journal of Asian Business Strategy, 6, 50-62. https://doi.org/10.18488/journal.1006/2016.6.3/1006.3.50.62

[24] Bagos, P.G. and Adam, M. (2015) On the Covariance of Regression Coefficients. Open Journal of Statistics, 5, 680-701. https://doi.org/10.4236/ojs.2015.57069

[25] Mason, C.H. and Perreault, W.D. (1991) Collinearity, Power, and Interpretation of Multiple Regression Analysis. Journal of Marketing Research, 28, 268-280. https://doi.org/10.2307/3172863

[26] ASQ's Quality Management Division (2002) Is There a Relationship-A Scatter Diagram Can Help You Determine If There's a Correlation between Two Variables. Quality Progress, 35, 120.

[27] Shu, X. (2005) Market Transition and Gender Segregation in Urban China. Social Science Quarterly, 86, 1299-1323. https://doi.org/10.1111/j.0038-4941.2005.00347.x

[28] Kim, J. (2013) Gender Difference in Employment and Income in China's Labor Market. The Journal of East Asian Affairs, 27, 31-53.

[29] Burnett, J. (2010) Women's Employment Rights in China: Creating Harmony for Women in the Workplace. Indiana Journal of Global Legal Studies, 17, 289-318. https://doi.org/10.2979/gls.2010.17.2.289

[30] Nathans, L.L., Oswald, F.L. and Nimon, K. (2012) Interpreting Multiple Linear Regression: A Guidebook of Variable Importance. Practical Assessment, Research \& Evaluation, 17, 1-19.

[31] Shen, W. and Lin, C. (2009) Firm Profitability, State Ownership, and Top Management Turnover at the Listed Firms in China: A Behavioral Perspective. Corporate Governance: An International Review, 17, 443-456. https://doi.org/10.1111/j.1467-8683.2009.00725.x

[32] Song, S. (2003) Policy Issues of China's Urban Unemployment. Contemporary Economic Policy, 21, 258-269. https://doi.org/10.1093/cep/byg009

[33] Zhang, L. and Dong, X.Y. (2008) Male-Female Wage Discrimination in Chinese Industry. Economics of Transition, 16, 85-112. https://doi.org/10.1111/j.1468-0351.2007.00317.x

[34] Wei, H., Yang, S., Liu, S., Wu, J. and Xiang, S. (2013) International Trade and Gender Wage Gap in China. European Scientific Journal, 9, 21-51.

[35] Bulger, C.M. (2000) Fighting Gender Discrimination in the Chinese Workplace. Boston College Third World Law Journal, 20, 345-391.

[36] Knight, T. (2016) Women and the Chinese Labor Market: Recent Patterns and Future Possibilities. The Chinese Economy, 49, 213-227. https://doi.org/10.1080/10971475.2016.1159907

[37] Liu, H. (2011) Economic Reforms and Gender Inequality in Urban China. Economic Development and Cultural Change, 59, 639-876. https://doi.org/10.1086/660006 